\title{
Category Code
}

National Cancer Institute

\section{Source}

National Cancer Institute. Category Code. NCI Thesaurus. Code C93524.

A coded value specifying a classification. 